Mairista, Fitri Eriyantil Efektvitas Pendistribusian Liquified Petroleum Gas (LPG) untuk Kapal Perikanan Nelayan dalam Rangka Pemberdayaan Nelayan Kecil di Kelurahan Pasia Nan Tigo

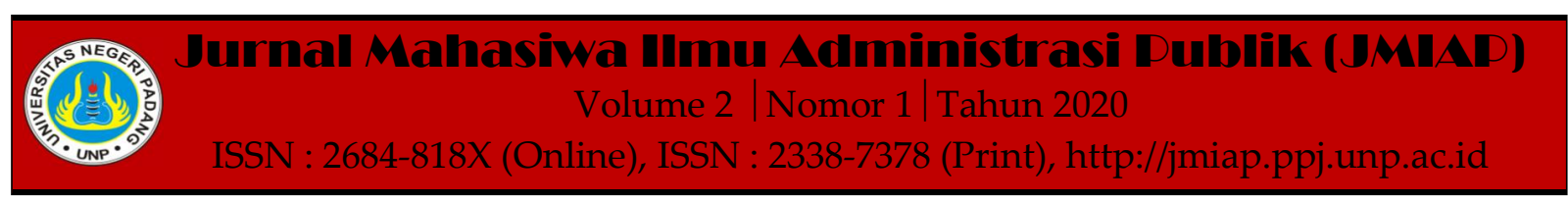

\title{
EFEKTVITAS PENDISTRIBUSIAN LIQUIFIED PETROLEUM GAS (LPG) UNTUK KAPAL PERIKANAN NELAYAN DALAM RANGKA PEMBERDAYAAN NELAYAN KECIL DI KELURAHAN PASIA NAN TIGO
}

\author{
Mairista $^{1(a)}$, Fitri Eriyanti2(b) \\ ${ }^{1}$ Jurusan Ilmu Administrasi Negara, Universitas Negeri Padang \\ ${ }^{2}$ Jurusan Ilmu Administrasi Negara, Universitas Negeri Padang \\ a)mairista97@gmail.com, ${ }^{b)}$ fitri.eriyanti@fis.unp.ac.id
}

\begin{abstract}
This article aims to analyze the effectiveness of the distribution of Liquified Petroleum Gas, hereinafter abbreviated as $L P G$ to fuel small fishing vessels in the framework of empowering fishermen in Pasia Nan Tigo Village, Koto Tangah District, Padang City.This article departs from the results of research on the effectiveness of the distribution of Liquified Petroleum Gas (LPG) for fishing vessels in the context of empowering small fishermen in Pasia Nan Tigo Village. Data is collected by observation, interview and documentation study. The research informants consisted of several stakeholders, namely the Padang City Maritime and Fisheries Service, PT. Pertamina Padang City, and fishermen who used LPG as fuel for fishing boats in Pasia Nan Tigo sub-district. The results showed the distribution of $L P G$ for boat fuel for fishermen in the framework of empowering small fishermen could not be said to be effective because the use of LPG assistance was not on target. The inhibiting factors of LPG distribution for ship fuel for fishermen in the framework of empowering small fishermen in Pasia Nan Tigo Village include: a) There is fear of fishermen using LPG as boat fuel due to the explosive nature of LPG. b) Unpreparedness of the fishing community in the village of Pasia Nan Tigo to switch to using $L P G$ as fuel for ships that previously used oil. c) Lack of supervision in the distribution of $L P G$ for fishing boat fuel. d) Insufficient $L P G$ is provided for fuel for fishing vessels which results in fishermen no longer using $L P G$ as fuel for their boats. e) The distribution of LPG is not targeted for the fuel of fishing boats because $L P G$ distributed to fishermen for boat fuel is used to burn the kitchen. $g$ ) There is no oversight carried out by PT. Pertamina Pertamina City and the Padang City Maritime and Fisheries Office in distributing LPG for boat fuel for fishermen in the framework of empowering small fishermen in Pasia Nan Tigo Village.
\end{abstract}

Keywords : Effectiveness, LPG, Empowerment, Fishermen

Corresponding author. Email.mairista97@gmail.com, fitri.eriyanti@fis.unp.ac.id

How to cite this article. Mairista \& Eriyanti. F. (2020). Efektvitas Pendistribusian Liquified Petroleum Gas (LPG) untuk Kapal Perikanan Nelayan dalam Rangka Pemberdayaan Nelayan Kecil di Kelurahan Pasia Nan Tigo. Jurnal Mahasiwa Ilmu Administrasi Publik (JMIAP) Jurusan Ilmu Administrasi Negara Fakultas Ilmu Sosial Universitas Negeri Padang, Volume 2 (1), Hal. 111-117.

http://jmiap.ppj.unp.ac.id

ISSN : 2684-818X (Online), ISSN : 2338-7378 (Print)

Copyright $\bigcirc 2020$. Published by Pusat Kajian-Pemberdayaan dan Pelayanan Masyarakat (PK-P2M) FIS UNP Padang 


\section{PENDAHULUAN}

Indonesia merupakan salah satu negara yang kaya akan hasil kelautan dan perikanan. Besarnya potensi kelautan dan perikanan yang dimiliki ternyata belum bisa mensejahterakan masyarakat terutama masyarakat pesisir yang bekerja sebagai nelayan terkhusus nelayan tradisional. Sebagian besar nelayan tradisional di Indonesia masih hidup dalam garis kemiskinan, Seharusnya dengan besarnya potensi kelautan yang dimiliki mampu memberikan kesejahteraan kepada masyarakat nelayan bukan sebaliknya.

Sumatera Barat merupakan salah satu Provinsi yang ada di Indonesia yang memiliki wilayah pesisir di tujuh Kabupaten dan Kota dengan luas laut kurang lebih $37.363,75 \mathrm{~km}^{2}$, dan Panjang garis pantai 1973,24 km, serta memiliki 185 pulau. Propinsi Sumatera Barat di pantai barat pulau Sumatera sangat menguntungkan karena potensi kelautan dan perikanannya sangat besar, akan tetapi pemberdayaan sektor perikanan belum optimal, sehingga belum bisa menghasilkan produktivitas yang signifikan terhadap perekonomian daerah ini. (Yenida, Elni Sumiarti, 2016).

Dalam rangka meningkatkan potensi kelautan dan perikanan, pemerintah telah mengatur kebijakan terkait pemberdayaan nelayan kecil melalui pendistribusian LPG di atur dalam Peraturan Presiden Republik Indonesia nomor 126 tahun 2015 yang bermakna bahwa adanya jaminanan ketersediaan dalam pendistribusian LPG sebagai bahan bakar gas bagi kapal nelayan. dalam pendistribusianya Kota Padang merupakan salah satu daerah yang menerima LPG untuk bantuan bahan bakar bagi kapal nelayan kecil. Pendistribusian LPG ini dilakukan pada tahun 2017 sebanyak 525 paket LPG di Kota Padang terkhusus di Kelurahan Pasia Nan Tigo 176 paket LPG. Kementrian ESDM yang bekerjasama dengan pemerintah Kota Padang terkhusus pada Dinas Kelautan Perikanan Kota Padang serta Pertamina yang menjadi distributor LPG melakukan pemberdayaan nelayan dalam bentuk pendistribusian LPG untuk kapal nelayan kecil.

Program pendistribusian LPG yang dirancang oleh pemerintah dan stakeholder kurang berjalan dengan baik karena sedikitnya partisipasi dari masyarakat nelayan dan tidak seseuainya LPG yang diberikan dengan fungsi LPG yang telah ditetapkan, sehingga pendistribusian LPG di Kelurahan Pasia Nan Tigo tidak efektif.

\section{TINJAUAN PUSTAKA \\ Efektivitas}

Efektivitas merupakan kemampuan dari organisasai dalam menjalankan tugas dan fungsi), serta program atau sejenisnya tanpa adanya tekanan atau ketegangan dalam proses pelaksanaannya (Rosalina, 2012 Vol.01, No.02).

Sedangkan menurut Handoko (2011:13) efektivitas adalah kemampuan memilih tujuan yang tepat atau peralatan yang tepat untuk pencapaian tujuan yang ditetapkan sebelumnya. Jadi efektivitas adalah suatu ukuran yang digunakan untuk melihat keberhasilan dari tujuan atau sasaran yang telah ditetapkan sebelumnya. Untuk mengukur efektifitas pendistribusian LPG untuk kapal perikanan nelayan dalam rangka pemberdayaan nelayan kecil menggunakan tolak ukur yang dikemukakan oleh Campbell (1989:121) yaitu sebagai berikut :

1) Keberhasilan program;

2) Keberhasilan sasaran;

3) Kepuasan terhadap program;

4) Tingkat input dan output;

5) Pencapaian tujuan menyeluruh.

\section{LIQUIFIED PETROLEUM GAS (LPG)}

Liquified Petroleum Gas (LPG) yang didistrubusikan kepada nelayan digunakan untuk bahan bakar kapal perikanan nelayan kecil. Menurut Wiyono ( 2017 Vol.1 No.1) LPG adalah bahan bakar gas yang berasal melalui proses distilasi bertekanan tinggi. Fraksi digunakan sebagai umpan yang dapat berasal dari beberapa sumber diantaranya Gas alam maupun Gas hasil 
Mairista, Fitri Eriyantil Efektvitas Pendistribusian Liquified Petroleum Gas (LPG) untuk Kapal Perikanan Nelayan dalam Rangka Pemberdayaan Nelayan Kecil di Kelurahan Pasia Nan Tigo

dari pengolahan minyak bumi (Light End). Liquified Petroleum Gas (LPG) yang didalamnya terdapat unsur karbon dan hidrogen yang merupakan senyawa hidrokarbon dengan komponen utama C3 dan $\mathrm{C} 4$.

Sifat LPG yang utama yaitu sebagai berikut:

1) Cairan dan gasnya sangat mudah terbakar;

2) Gas tidak beracun, tidak berwarna dan berbau menyengat;

3) Gas dikirimkan sebagai cairan yang bertekanan di dalam tangki atau silinder;

4) Cairan bisa menguap jika dilepas dan menyebar dengan cepat;

5) Gas LPG lebih berat dibandingkan udara sehingga akan banyak menempati daerah yang lebih rendah.

Berdasarkan penjelasan di atas dapat dipahami bahwa LPG merupakan bahan bakar gas yang digunakan oleh nelayan sebagai bahan bakar untuk menggenggerakan kapal nelayan dalam melakukan penagkapan ikan.

\section{Pemberdayaan Nelayan}

Menurut Mardikanto,dkk (2015:28) pemberdayaan bisa diartikan suatu proses yang menjadikan masyarakat untuk lebih kuat dan ikutserta di dalam berbagai pengontrolan, dan lembaga-lembaga yang mempengaruhi kehidupan masyarakat tersebut.

Sedangkan Suhendra (2006:74) mengatakan bahwa pemberdayaan merupakan kegiatan berkelanjutan, dinamis, yang mendorong keterlibatan semua potensi secara evolutif, dengan keterlibatan semua potensi.

Berdasarkan pendapat di atas bisa dijelaskan pemberdayaan yaitu upaya peningkatan harkat serta martabat masyarkat dan memampukan yang belum mampu hingga menjadi masyarakat yang mampu dan lebih mandiri dan bisa keluar dari lingkaran kemiskinan.

proses pemberdayaan masyarakat perlu melakukan tahapan penyadaran, dan transformasi kemampuan sehingga bisa meningkatkan kemampuan intelektual masyarakat yang mengantarkan masyarakat tersebut pada kemandirian.

\section{Nelayan Kecil}

Menurut Damayanti (2016 Vol.XII, No.2) nelayan kecil adalah nelayan tradisional yang melalui program pembaharuan alat tangkap dan perahu maka masyarakat nelayan tidak lagi menggunakan perahu tradisional maupun alat tangkap yang konvensional, melainkan menggunakan mesin otor tempel, sehingga wilayah penangkapan menjadi lebih jauh atau agak meluas.

Dalam Peraturan Presiden RI nomor 126 tahun 2015 telah dijelaskan bahwa nelayan kecil yaitu masyarakat nelayan yang dalm kesehariannya melakukan penangkapan ikan untuk kelangsungan hidupnya dengan menggunakan alat tangkap tradisional dan kapal perikanan dengan ukuran paling besar 5 (lima) gros ton (GT).

Berdasarkan paparan di atas bisa dipahami bahwa nelayan kecil merupakan masyarakat nelayan yang dalam kesehariannya menangkap ikan dengan peralatan yang sederhana untuk kelangsungan hidupnya. Nelayan kecil menggantungkan kehidupannya langsung kepada hasil laut, nelayan kecil biasanya tinggal di bibir pantai atau di pinggiran pantai, dekat dengan lokasi pekerjaan yang dilakukan sehari-hari.

\section{METODE PENELITIAN}

Penelitian ini menggunakan pendekatan kualitatif dengan metode deskriptif. Penelitian dilakukan di Kelurahan Pasia Nan Tigo Kecamatan Koto Tangah Kota Padang. Pemilihan informan menggunakan teknik purposive sampling. Data dikumpulkan dengan observasi/pengamatan, wawancara dan studi dokumentasi. Penguji keabsahan data dengan teknik triangulasi sumber dan metode. sehingga data yag didapat bisa ditarik kesimpulannya dari data yang sudah di peroleh. 


\section{HASIL DAN PEMBAHASAN}

LPG yang diberikan kepada nelayan digunakan sebagai bahan bakar untuk kapal nelayan kecil yang telah diatur dalam Peraturan Presiden Nomor 126 tahun 2015 dimana dalam peraturan ini telah di atur tentang pendistribusian LPG untuk bahan bakar kapal nelayan. Berkaitan dengan efektivitas pendistribusian LPG untuk kapal perikanan nelayan dalam rangka pemberdayaan nelayan kecil di kelurahan Pasia Nan Tigo dilihat dari lima tolak ukur efektifitas yang dikemukakan oleh Campbell (1989:121) yaitu sebagi berikut :1)Keberhasilan program. 2)Keberhasilan Sasaran. 3)Kepuasan terhadap program. 4)Tingkat input dan Output. 5)Pencapaian tujuan menyeluruh.

\section{Keberhasilan Program}

Campbell (1989:121) mengatakan efektivitas program bisa berjalan melalui kemampuan yang operasional dalam melaksanakan program yang telah ditetapkan. Berdasarkan penelitian yang telah dilakukan, pendistribusian LPG sebagai bahan bakar bagi kapal nelayan kecil di kelurahan Pasia Nan Tigo belum bisa dikatakan berhasil karena dalam pendistribusiannya terlihat bahwa tidak semua nelayan yang mendapatkan bantuan LPG menggunakan LPG sebagai bahan bakar untuk kapal nelayan karena tidak cukupnya atau langkanya LPG.

Berdasarkan pendapat Karundeng (2018 Vol.6 No.3) terdapat 4 (empat) faktor penting dalam kegiatan distribusi salah satunya adalah ketersediaan barang/jasa. Ketersediaan menyangkut barang jadi, bahan setengah jadi, bahan baku, dan lain sebagainya, agar tidak terjadi kekurangan barang atau stok barang dari jumlah yang telah diorder sebelumnya oleh konsumen. Dari pendapat Karundeng di atas terlihat bahwa ketersediaan LPG untuk bahan bakar kapal nelayan kecil menentukan keberhasilan dari pelaksanaan program pendistribusian LPG tersebut. Akan tetapi pendapat Karundeng di atas tidak sesuai dengan peneliti temukan di lapangan karena banyak dari nelayan kesulitan untuk mendapatkan LPG sebagai bahan bakar kapal nelayan.

\section{Keberhasilan Sasaran}

Menurut Lizard (2017 Vol.2 No.2) tepat sasaran adalah ketepatan pemberian bantuan program pemberdayaan kepada mereka yang dianggap sangat layak untuk menerima, Lebih lanjut Budiani (2007:52) mengatakan bahwa ketepatan sasaran suatu program harus sesuai dengan sasaran atau peserta program yang telah ditetapkan.

Dari pendapat lizard dan budiani bisa dijelaskan keberhasilan sasaran pada pendistribusian LPG untuk kapal perikanan nelayan kecil belum bisa dikatakan berhasil karena dalam pendistribusian LPG sebagai bahan bakar bagi kapal yang menjadi sasarannya seharusnya adalah nelayan kecil atau nelayan tradisional yang memiliki kartu nelayan, akan tetapi gas yang dikhususkan untuk nelayan yang telah dijelaskan diatas diberikan untuk umum atau masayarakt yang tidak berprofesi sebagai nelayan, dan tidak semua nelayan yang mendapatkan LPG sebagai bahan bakar kapal nelayan.

\section{Kepuasan Terhadap Program}

Menurut Dwi Sadono, dkk (2014 Vol.1 No.1) kepuasan atau ketidakpuasan dari masyarakat ditentukan oleh persepsi dan harapan masyarakat. Persepsi terhadap program yang didistribusiakan dipengaruhi oleh pengalaman masyarakat saat menerima dan menggunakan produk dari program yang telah disitribusikan kepada masyarakat. Nelayan di kelurahan Pasia Nan Tigo merasa tidak puas dengan program pendsitribusian LPG sebagai bahan bakar kapal nelayan. Ketidakpuasan nelayan tersebut dapat terlihat dari sedikitnya nelayan yang menggunakan LPG sebagai bahan bakar bagi kapal nelayan karena pengadaan gas yang tidak optimal, sehingga nelayan di kelurahan Paia Nan Tigo mayoritas memilih untuk menggunakan minyak sebagai bahan bakar 
Mairista, Fitri Eriyantil Efektvitas Pendistribusian Liquified Petroleum Gas (LPG) untuk Kapal Perikanan Nelayan dalam Rangka Pemberdayaan Nelayan Kecil di Kelurahan Pasia Nan Tigo

kapal mereka dibandingkan menggunakan LPG.

\section{Tingkat Input dan Output}

Kesesuaian antara input dan output pada program pendistribusian LPG untuk kapal nelayan belum efektif, karena menurut Zaidan (2013:188) efektivitas merupakan kesesuaian antara output dan tujuan, dimana efektivitas di ukur berdasarkan seberapa jauh tingkat output, kebijakan dan prosedur dari organisasi untuk mencapai suatu tujuan yang telah ditetapkan sebelumnya. Dalam hal ini tujuan pendistribusian LPG untuk kapal perikanan nelayan di kelurahan Pasia Nan Tigo tidak sepenuhnya tercapai karena masih banyak nelayan yang tidak menggunakan LPG untuk bahan bakar kapal mereka, dan pendistribusian LPG sebagai bahan bakar bagi kapal nelayan kecil yang didistribusikan pada tahun 2017, dan tidak semua nelayan kecil yang mendapatkan LPG sebagai bahan bakar kapal nelayan karena dari 7069 orang nelayan hanya 525 yang mendapatkan LPG sebagai bahan bakar kapal nelayan.

\section{Pencapaian Tujuan Menyeluruh}

Menurut Budiani (2007:52) tujuan suatu program pemberdayaan berkaitan dengan sejauhmana hasil nyata dari program dengan tujuan yang telah ditetapkan sebelumnya, pendapat Budiani tersebut bertolak belakang dengan yang peneliti temui di lapangan, karena pencapaian tujuan secara menyeluruh dari pendistribusian LPG sebagai bahan bakar kapal nelayan kecil terlihat dari nelayan yang terbantu dalam melakukan pekerjaannya yaitu melaut. Namun pencapaian tujuan menyeluruh dalm pendistribusian LPG sebagai bahan bakar kapal nelayan kecil tidak sepenuhnya berhasil karena dalam pendistribusian LPG sebagai bahan bakar kapal nelayan seharusnya bisa mempermudah nelayan dalam mendapatkan bahan bakar, akan tetapi tujuan tersebut tidak sesuai dengan yang diharapakn karena masih banyak nelayan di kelurahan Pasia Nan Tigo kesulitan untuk mendapatkan bahan bkara kapal mereka. Dari lima indikator yang dikemukakan Campbell (1989:121), yang digunakan untuk mengukur efektif atau tidaknya suatu program pendistribusian LPG bagi kapal perikanan nelayan kecil di kelurahan Pasia Nan Tigo tidak sejalan dengan apa yang peneliti temukan di lapangan karena dalam pendistribusian LPG untuk bahan bakar kapal nelayan kecil di kelurahan Pasia Nan Tigo masih banyak permasalahan yang peneliti temui dalam proses pendistribusian seperti nelayan yang sulit mendapatkan bahan bakar gas untuk kapal nelayan dan LPG yang disediakan tidak tepat sasaran.

Faktor penghambat pendistribusian LPG untuk kapal perikanan nelayan dalam rangka pemberdayaan nelayan kecil di kelurahan Pasia Nan Tigo

Dalam pendistribusian LPG untuk kapal perikanan nelayan kecil di kelurahan Pasia Nan Tigo masih terdapat beberapa faktor penghamabat yaitu sebagai berikut:

a) Adanya ketakutan dari nelayan untuk menggunakan LPG sebagai bahan bakar kapal karena sifat LPG yang juka dalam penggunaannya tidak hati-hati akan mudah meledak.

b) Ketidaksiapan masyarakat nelayan di kelurahan Pasia Nan Tigo untuk beralih menggunakan LPG sebagai bahan bakar kapal yang sebelumnya menggunakan minyak.

c) Kurangnya pengawasan dalam pendistribusian LPG untuk bahan bakar kapal nelayan.

d) Sulitnya nelayan untuk mendapatkan LPG sebagi bahan bakar kapal yang mengakibatkan nelayan tidak lagi menggunakan LPG sebgai bahan bakar kapal mereka. 
Mairista, Fitri Eriyanti| Efektvitas Pendistribusian Liquified Petroleum Gas (LPG) untuk Kapal Perikanan Nelayan dalam Rangka Pemberdayaan Nelayan Kecil di Kelurahan Pasia Nan Tigo

Solusi untuk mengatasi faktor pengahambat dalam pendistribusian LPG sebagai bahan bakar kapal di kelurahan Pasia Nan Tigo

Solusi yang digunakan oleh pemerintah dan stakeholder dalam mengatasi faktor penghamabat dalam pendistribusian LPG untuk kapal perikanan nelayan kecil di Kelurahan Pasia Nan Tigo yaitu dengan melakukan pengawasan dalam pengadaan LPG yang disediakan setiap minggunya terutama di kelurahan Pasia Nan Tigo, dan melakukan sosialisasi kembali terkait penggunaan LPG sebagai bahan bakar kapal supaya nelayan kecil di kelurahan Pasia Nan Tigo menggunakan LPG sesuai dengan tujuan dan fungsi pendistribusian LPG itu sendiri yaitu sebagai bahan bakar kapal nelayan. Selain itu, pemerintah dan instansi terkait juga berupaya untuk memaksimalkan pengadaan LPG kepada nelayan supaya nelayan tidak kesulitan lagi untuk mendapatkan LPG untuk bahan bakar kapal mereka. Hal ini dilakukan untuk memudahkan nelayan dalam melaut sehingga ketergantungan nelayan terhadap bahan bakar minyak berkurang.

\section{PENUTUP}

Berdasarkan hasil penelitan di atas dapat disimpulkan: (1) Pendistribusian LPG yang dilakukan oleh pemerintah kepada nelayan terutama nelayan di kelurahan Pasia Nan Tigo tidak berjalan efektif karena terlihat dari masih banyaknya nelayan yang menerima bantuan LPG menggunakan minyak sebagai bahan bakar kapal nelayan. (2) LPG yang didistribusikan dan disediakan tiap minggunya kepada nelayan di kelurahan Pasia Nan Tigo tidak tepat sasaran karena banyaknya konsumen yang bukan nelayan mendapatkan LPG tersebut dan dipergunakan untuk keperluan dapur tidak untuk kapal nelayan. (3) Faktor yang menjadi kendala dalam pendistribusian LPG di kelurahan Pasia Nan Tigo adalah sulitnya nelayan mendapatkan LPG serta adanya ketakutan nelayan dalam menggunakan LPG karena sifat LPG yang mudah meledak dan terbakar.

\section{DAFTAR KEPUSTAKAAN}

Budiani, Ni Wayan. Efektivitas Program Penanggulangan Pengangguran Karang Taruna "Eka Taruna Bakti" Desa Sumerta Kelod Kecamatan Denpasar Timur Kota Denpasar. Jurnal Input.Vol.2 No.1, 2007:53.

Campbell.1989. Riset dalam Efektivitas Organisasi. Terjemahan Sahat Simamora. Jakarta: Erlangga. 121 hal.

Handoko, T. Hani.2001.Manajemen Personalia dan Sumber Daya Manusia. Yogyakarta: BPFE Yogyakarta.

Thessa Natasya Karundeng, dkk. Analisis Saluran Distribusi Kayu (Studi Kasus di CV.Karya Abadi, Manado)Jurnal EMBA. Vol.6 No.3, Juli 2018:1749.

K.Suhendra.2006. Peranan Birokrasi dalam Pemberdayaan Masyarakat.Bandung: Alfabeta. 75-87 hal.

Revly Sian Lizard, dkk. Efektivitas Program Pemberdayaan Masyarakat Miskin di Kelurahan Paal Dua Kecamatan Paal Dua Kota Manado. Jurnal Ilmu Pemerintahan. Vol.2 No.2, 2017.

Totok Mardikanto, dkk.2015.Pemberdayaan Masyarakat Dalam Persepektif Kebijakan Publik. Bandung: Alfabeta.28 hal.

Rosalina, I. Efektivitas Program Nasional Pemberdayaan Masyarakat Mandiri Perkotaan Pada Kelompok Pinjaman Bergilir di desa Mantren Kecamatan Karangrejo Kabupaten Magetan. Jurnal Header. Vol.01, No.02, 2012.

Adi Wiyono, dkk.Rancang Bangun Sistem Deteksi dan Pengaman Kebocoran Gas Berbasis Algoritma Bahasa C Menggunakan sensor Mq-6. Jurnal KOMIK (Konferensi Nasional 
Mairista, Fitri Eriyanti| Efektvitas Pendistribusian Liquified Petroleum Gas (LPG) untuk Kapal Perikanan Nelayan dalam Rangka Pemberdayaan Nelayan Kecil di Kelurahan Pasia Nan Tigo

Teknologi Informasi dan Komputer).

Vol.1 No.1, Oktober 2017:79.

Yenida, Elni Sumiarti.2016.Efektivitas Program Pemberdayaan Ekonomi Masyarakat Miskin di Wilayah Pesisir Pantai Sumatera Barat. National.

Zaidan, N. 2013. Manajemen

Pemerintahan. Jakarta: PT Raja Grafindo. 